logos_i_ethos_2020_2_(55), s. 129-148

DOI: http://dx.doi.org/10.15633/lie.3811

Tymoteusz Mietelski

https://orcid.org/0000-0001-5279-4648

Akademia Ignatianum w Krakowie

\title{
Filozoficzna droga Paola Valoriego
}

Według Ryszarda Kijowskiego wydane na przełomie 1900 i 1901 roku Badania logiczne Edmunda Husserla są uznawane za jedno z najbardziej wpływowych dzieł filozoficznych ${ }^{1}$. Filozof sam był zdziwiony, jak wielki wpływ ono wywarło. Po latach powiedział z żalem: „była to zupełnie drobniutka praca debiutanta - a wedle tych Logische Untersuchungen osądza się Husserla dzisiaj. Tymczasem po ich ukazaniu się ja przez długie lata nie wiedziałem dobrze, co z tego wyniknie. Sam sobie nie zdawałem jasno sprawy, a teraz pech chce, że tej książki wszyscy się uczepili”' . Chodziło mu zapewne o rozwój jego filozofii i niedostateczne zainteresowanie i zrozumienie późniejszych koncepcji.

Właśnie wydanie Badań logicznych z zawartym w nich postulatem „powrotu do rzeczy samych” można uznać za datę przełomową $\mathrm{w}$ powstawaniu fenomenologii. W niektórych krajach myśl Husserla od razu wywoływała reakcje, a fenomenologia stawała się ważnym kierunkiem filozoficznym. W innych rozwój następował $\mathrm{z}$ opóźnieniem. Tak było we Włoszech, gdzie z powodów

1 Zob. R. Kijowski, Fenomenologia Edyty Stein, w: Edyta Stein - filozof i świadek epoki. Materiały z Międzynarodowego Sympozjum w Opolu - Kamieniu Śląskim w dniach 9-10.04.1997, red. J. Piecuch, Opole 1997, s. 20-21.

2 A. Jaegerschmid, Rozmowy z Edmundem Husserlem (1931-1938), „Znak” 1972 nr 212, s. 165. 
politycznych wiodącym kierunkiem filozoficznym był idealizm w różnych odmianach $^{3}$. Pierwszym badaczem zajmującym się we Włoszech fenomenologią był Antonio Banfi ${ }^{4}$. W 1923 roku w czasopiśmie „Rivista di filosofia" opublikował dwa artykuły dotyczące filozofii Husserla ${ }^{5}$. Wcześniej żaden badacz włoski nie zajmował się problematyką fenomenologiczną. Dopiero na przełomie lat dwudziestych i trzydziestych XX wieku pojawia się zainteresowanie myślą niemieckiego myśliciela ${ }^{6}$. Rozkwit myśli fenomenologicznej we Włoszech przypada na przełom lat pięćdziesiątych i sześćdziesiątych ${ }^{7}$.

Jednym z ważniejszych przedstawicieli tej epoki był włoski jezuita Paolo Valori. Filozof ten jest prawie zupełnie nieznany w Polsce ${ }^{8}$. Żadna jego praca nie została przetłumaczona na język polski. Niniejszy artykuł ma charakter przeglądowy, jego celem jest przedstawienie twórczości Valoriego. Jaka była jego filozoficzna droga do fenomenologii? Jak dochodził do koncepcji etyki fenomenologicznej? Jaki był jego punkt wyjścia? Jaką metodę badania moralności przyjął? - Oto pytania, na które postaramy się odpowiedzieć.

3 Por. A. Kobyliński, Włoska droga do fenomenologii. Paolo Valori - interpretacja doświadczenia moralnego, w: Dziedzictwo etyki współczesnej. Aksjologia i etyka Romana Ingardena i jego uczniów. Studia i rozprawy, red. P. Duchliński, Kraków 2015, s. 313-314.

4 Por. C. Sini, La fenomenologia in Italia, „Revue Internationale de philosophie” 1965 n. 71/72, s. 125 .

Dzieła, których tytuły podane są w tekście głównym lub przypisach w języku włoskim, w szczególności wszystkie teksty Valoriego, nie zostały przełożone na język polski. Wszystkie cytaty to tłumaczenia własne autora artykułu.

5 Por. A. Banfi, La tendenza logistica della filosofia tedesca contemporanea e le „Ricerche logiche” di Edmund Husserl, „Rivista di filosofia” 14 (1923) q. 2, s. 115-133; A. Banfi, La fenomenologia pura di E. Husserl e l'autonomia ideale della sfera teorica, „Rivista di filosofia” 14 (1923) q. 3, s. 208-224.

6 Por. M. Mocchi, Le prime interpretazioni della filosofia di Husserla in Italia. Il dibattito sulla fenomenologia: 1923-1940, Firenze 1990, s. 1.

7 Por. A. Kobyliński, Włoska droga..., dz. cyt., s. 314.

8 Ukazały się dwa teksty dotyczące jego poglądów: cytowany wyżej artykuł naukowy A. Kobyliński, Włoska droga..., dz. cyt., s. 313-330 oraz podrozdział w monografii - P. Duchliński, A. Kobyliński, R. Moń, E. Podrez, Inspiracje chrześcijańskie w etyce, Kraków 2016, s. 170-185. 
Paolo Valori przyszedł na świat 28 marca 1919 roku w Bolonii, w rodzinie włoskich intelektualistów. Jego ojciec to Aldo Valori ${ }^{9}$, słynny dziennikarz „Nazione”, „Resto del Carlino”, „Corriere della Sera” i „Messagero”. Jego brat, Michele Valori, był cenionym architektem, a siostra, Bice Valori, znaną aktorką. Rodzina Valorich przeprowadziła się w 1923 roku do Rzymu. Tam Paolo uczęszczał do gimnazjum i liceum w jezuickim Instituto Massimo, a następnie 12 listopada 1937 roku wstąpił do Towarzystwa Jezusowego w Galloro.

Po przyjęciu w 1948 roku święceń rozpoczął działalność naukową w dziedzinie filozofii. Przez 3 lata wykładał w jezuickim Liceum Mondragone, następnie przez ponad 26 lat w Papieskim Uniwersytecie Laterańskim oraz od 1967 roku do emerytury w Papieskim Uniwersytecie Gregoriańskim. Przystąpił również do Movimento di Gallarate, obecnie Fondazione Centro Studi Filosofici di Gallarate przy Instytucie Filozoficznym Aloisianum.

Kilka lat przed śmiercią został przeniesiony do infirmerii jezuitów w Rzymie. Zmarł 23 grudnia 2003 roku w południe w Szpitalu Ducha Świętego w Rzymie ${ }^{10}$.

\section{Analiza myśli Maurice’a Blondela}

Pierwszym ważnym dziełem Valoriego było studium myśli Maurice’a Blondela (1861-1949) ${ }^{11}$. Był on francuskim filozofem próbującym integrować myśl neoplatońską z nowożytnym pragmatyzmem w kontekście chrześcijańskiej filozofii religii. Valori twierdzi, że jesteśmy świadkami "gigantycznej walki [...] między najuboższą filozofią - materializmem,

9 W 2003 roku zostały opublikowane jego wspomnienia: A. Valori, Il fascista che non amava il regime, a cura di V. Tonelli Valori, Roma 2003.

10 Por. F. Egaña, In memoriam: P. Paolo Valori, „La Gregoriana. Trimestrale della Pontificia Università Gregoriana” 2004 n. 20, s. 29.

11 P. Valori, M. Blondel e il problema d'una filosofia cristiana, Roma 1950. Wcześniej publikuje dwa artykuły dotyczące Blondela: Il problema del soprannaturale e gli ultimi scritti di M. Blondel, "Civiltà Cattolica" 1 (1949) n. 100, s. 161-170 oraz Il soprannaturale e gli ultimi scritti di M. Blondel, „Civiltà Cattolica” 1 (1949) n. 100, s. 392-399. 
który próbuje wstrząsnąć podstawami etyczno-społecznymi cywilizacji zachodniej i narzucić ideę uspołecznionej techniki - oraz filozofią spirytualistyczną, która próbuje bronić pojęć własności, personalizmu i wolności, uważanych za jej największą zdobycz" ${ }^{12}$. Według Valoriego pojawia się zatem pytanie o rolę chrześcijaństwa w tym sporze, a szerzej o możliwość dialogu filozofii, lub ogólniej, nauki współczesnej i chrześcijaństwa ${ }^{13}$. Włoski myśliciel przedstawia zarys problemu filozofii chrześcijańskiej w historii, zwracając uwagę na rozwiązania epoki patrystycznej, św. Augustyna, św. Tomasza, scholastyki oraz współczesną sobie dyskusję (Gilson, Bréhier, Maritain, De Lubac, Castelli). Omawia myśl Blondela, odnotowując, że problem filozofii chrześcijańskiej nie jest u niego tylko ,jednym z rozdziałów”, ale „duszą, centrum i motywem inspirującym" jego systemu ${ }^{14}$. Blondel, według Valoriego, rozróżnia porządek naturalny i nadprzyrodzony, ale ich nie rozgranicza, postuluje raczej ich wspólistnienie. Takie podejście jest jego zdaniem zgodne z prawidłowo odczytaną myślą Augustyna, Tomasza i całą tradycją chrześcijańską ${ }^{15}$.

Valori przedstawia i poddaje krytycznej analizie rozwiązania postulowane przez Blondela. Twierdzi, że jego myśl wzbudza „podziw i intelektualną radość z powodu harmonijnej spójności i wyczerpującej integralności, $\mathrm{z}$ jaką wymykający się i wieloaspektowy problem został postawiony, wyjaśniony [...] i rozwiązany w syntezie satysfakcjonującej intelekt i pocieszającej serce"16. Przy wejściu jednak w rozwiązania szczegółowe pojawiają się pytania i wątpliwości, na przykład: sprawa desiderium naturalis et efficax beatidunis, którą Blondel uważał za węzeł gordyjski całego zagadnienia ${ }^{17}$. Chodzi mianowicie o naturalną tendencję, wyprzedzającą interwencję łaski, do osiągnięcia szczęśliwości nadprzyrodzonej. Valori stawia pytania: czy ta tendencja jest wrodzona czy też

12 P. Valori, M. Blondel..., dz. cyt., s. 7.

13 Zob. P. Valori, M. Blondel..., dz. cyt., s. 9.

14 Zob. P. Valori, M. Blondel..., dz. cyt., s. 101.

15 Zob. P. Valori, M. Blondel..., dz. cyt., s. 54.

16 P. Valori, M. Blondel..., dz. cyt., s. 145-146.

17 Zob. P. Valori, M. Blondel..., dz. cyt., s. 153. 
nabyta, czy jest to pragnienie realne czy tylko hipotetyczne, jak pogodzić pragnienie nadprzyrodzoności ze szczęśliwością naturalną, jak rozumieć naturalne pragnienie nadprzyrodzoności (,jak natura może przekraczać swoje granice?") ${ }^{18}$. Skrupulatnie analizuje poglądy Blondela, przedstawia stanowiska zbieżne i przeciwne, prowadzi korespondencję $\mathrm{z}$ francuskim filozofem, którą przedstawia w przypisach oraz prezentuje własną koncepcję. We wnioskach zarzuca Blondelowi niejasne przedstawienie stanowiska (niedostateczne zdefiniowanie i niewystarczający opis natury desiderium naturale) i ryzykowne uczynienie z tezy o desiderium fundamentu każdej spekulacji filozoficznej ${ }^{19}$.

Ostatecznie według Valoriego można przyjąć koncepcję filozofii chrześcijańskiej Blondela $\mathrm{z}$ doprecyzowaniami i zastrzeżeniami. Zasługą francuskiego filozofa jest, według Valoriego, utrzymywanie ,istnienia w naszej aktualnej naturze niezaspokojenia, pragnienia skierowanego wobec czegoś, co nie jest czysto naturalne, czyli wobec czegoś nadprzyrodzonego" ${ }^{20}$. Zdaniem Valoriego pojawienie się tej tezy, wcześniej zapomnianej, w teologii, przepowiadaniu, w filozofii chrześcijańskiej dokonało się właśnie dzięki Blondelowi. Jest to niezwykle istotne, ponieważ ta teza może być „pierścieniem łączącym naturalne i nadprzyrodzone poznanie Boga, filozofię i teologię, rozum i wiarę" ${ }^{21}$. W ten sposób dochodzi do dialogu chrześcijaństwa z myślą współczesną. Włoski myśliciel powiada: „tylko w szczęśliwym zjednoczeniu filozofii i chrześcijaństwa, tego, co naturalne i co nadprzyrodzone, rozumu i wiary, ludzkość odnajdzie równowagę. [...] W tej tezie zawiera się [...] najgłębsze i najtrwalsze znaczenie dzieła Blondela"22.

18 Zob. P. Valori, M. Blondel..., dz. cyt., s. 158, 177.

19 P. Valori, M. Blondel..., dz. cyt., s. 184.

20 P. Valori, M. Blondel..., dz. cyt., s. 231.

21 P. Valori, M. Blondel..., dz. cyt., s. 231.

22 P. Valori, M. Blondel..., dz. cyt., s. 234. 


\section{Początek zainteresowania fenomenologią Husserla}

Valori zainteresował się następnie myślą Husserla. W 1952 roku pisze recenzję wydanych w 1950 roku Die Idee der Phänomenologie ${ }^{23}$ - pięciu niepublikowanych wcześniej wykładów Husserla będących wprowadzeniem do fenomenologii. Valori twierdzi, że jest to istotna pozycja, ponieważ świadczy o formułowaniu przez niemieckiego filozofa ważnych dla fenomenologii tez - „intuicja ejdetyczna, konstytucja przedmiotu świadomości, a zwłaszcza słynna redukcja fenomenologiczna" ${ }^{24}$ - już w 1907 roku, kiedy wygłaszał owe pięć wykładów.

W następnych latach publikuje kolejne artykuły, fragmenty prac zbiorowych i hasła encyklopedyczne dotyczące fenomenologii. Tłumaczy również fragmenty niewydanych rękopisów Husserla ${ }^{25}$.

Lata badań, prowadzonych także w Archiwum Husserla w Leuven, wieńczy w 1959 roku książka Il metodo fenomenologico e la fondazione della filosofia ${ }^{26}$. Dzieło to ma charakter historyczny, ale, jak zauważa Valori, nie jest pozbawione aspektów teoretycznych ${ }^{27}$. Książka znajduje szeroki odzew w postaci ponad dwudziestu recenzji w czasopismach naukowych włoskich, hiszpańskich, francuskich, amerykańskich i kanadyjskich.

Włoski myśliciel powiada: „studium, zwłaszcza myśli współczesnej, doprowadziło nas do oczywistej, choć często zapomnianej i zakrytej konstatacji, że problem fundamentu [...] a zatem natury i poprawnej procedury filozofowania jest warunkiem koniecznym każdego poważnego rozwoju spekulatywnego, a jako taki jest problemem nieuniknionym dla każdego, kto zechce świadomie zachować dla aktywności

23 E. Husserl, Die Idee der Phänomenologie. Fünf Vorlesungen, Haag 1950.

24 P. Valori, E. Husserl, Die Idee der Phänomenologie. Fünf Vorlesungen, „Gregorianum” 33 (1952) n. 1 , s. 196.

25 E. Husserl, Dal manoscritto inedito K III 26, P. Valori (tłum.), „Archivio di filosofia” 22 (1954) n. 1, s. 173-175; E. Husserl, Dal manoscritto inedito K III 28, P. Valori (tłum.), „Archivio di filosofia” 22 (1954) n. 1, s. 168-172; zob. P. Valori, Inediti husserliani sulla teleologia della storia, „Archivio di filosofia" 22 (1954) n. 1, s. 165-167.

26 P. Valori, Il metodo fenomenologico e la fondazione della filosofia, Città di Castello 1959.

27 Zob. P. Valori, Il metodo fenomenologico..., dz. cyt., s. 1. 
filozoficznej specyficzny status odrębny od innych przejawów ducha"28. Fenomenologia jawi się zatem dla niego jako odpowiedź na pytanie o fundament i naturę filozofii, fundament nie tyle logiczno-ontologiczny, ile krytyczno-epistemologiczny ${ }^{29}$.

Valori twierdzi, że poza nielicznymi wyjątkami, metodologia Husserla nie znalazła odzewu we Włoszech na skalę taką jak we Francji, Belgii czy USA. Powiada: „oficjalna filozofia [...] nie mogła logicznie widzieć $\mathrm{w}$ intuicjonizmie fenomenologicznym czegoś innego niż rudymentarnej formy zaniku realizmu"30. Trochę większe znaczenie zyskała fenomenologia, jak twierdzi Valori, w środowiskach egzystencjalistów i neoscholastyków.

Włoski filozof zauważa, że metodologia fenomenologiczna może być płaszczyzną działania dla wszystkich, którzy są „,rozczarowani konstrukcjami systematycznymi budowanymi $a$ priori i chaotycznym wirem przeciwstawnych opinii”" ${ }^{\prime 3}$. Twierdzi, że „żadna erystyka [...], żaden wysiłek, żaden zbiór faktów i propozycji nie będą mogły nigdy, jak się wydaje, zastąpićzadania [...], którezechciała przyjąćfenomenologia Husserla: wiernego i całościowego [...] wyjaśnienia źródłowego dawania się rzeczy samych" ${ }^{32}$.

Valori analizuje rozwój fenomenologii w aspekcie historycznym, nadając kolejnym fazom itinerarium Husserlowskiego, jak je określa, specyficzne nazwy. I tak po wstępnej fazie psychologizmu, mamy Badania logiczne - „walka antypsychologistyczna i narodziny fenomenologii”, Idee - „Ukonstytuowanie fenomenologii”, Medytacje kartezjańskie i Logika formalna i transcendentalna - „Nacisk na moment metafizyczny”, a następnie Doświadczenie isq̨d oraz Kryzys nauk w Europie - „od fenomenologii do egzystencjalizmu". Taki podział historii fenomenologii wprowadził już w artykule Storia della fenomenologia husserliana z $1956 \mathrm{roku}^{33}$.

28 P. Valori, Il metodo fenomenologico..., dz. cyt., s. 1.

29 Zob. P. Valori, Il metodo fenomenologico..., dz. cyt., s. 1.

30 P. Valori, Il metodo fenomenologico..., dz. cyt., s. 27.

31 P. Valori, Il metodo fenomenologico..., dz. cyt., s. 28.

32 P. Valori, Il metodo fenomenologico..., dz. cyt., s. 28.

33 P. Valori, Storia della fenomenologia husserliana, w: La fenomenologia, a cura di C. M. Antonelli, Brescia 1956, s. 68-84. 
Valori poddaje analizie strukturę metodyczną fenomenologii, badając najważniejsze zagadnienia filozofii Husserla, którymi są: filozofia jako nauka ścisła, problem początku filozofii, oczywistość, prawda, intuicja ejdetyczna, analiza intencjonalna, epochè, intersubiektywność, solipsyzm. Drobiazgowa analiza prowadzi do stwierdzenia, że punktem wyjścia fenomenologii jest koncepcja filozofii jako: nauki ścisłej, choć nie tak jak matematyka, czy fizyka; czysto teoretycznej, odróżniającej się wyraźnie od historiografii, od wyrażania uczuć lirycznych, od Weltanschauung (światopoglądu); odnoszącej się do specyficznego typu doświadczenia, nieredukowalnego do innych typów doświadczeńn ${ }^{34}$. Takie „doświadczanie czyste to intuicja rzeczy samych, intuicja rzeczywistości przed-orzecznikowej, do której analiza filozoficzna będzie musiała dostosować jak najlepiej swoje metody postępowania" ${ }^{\text {"3 }}$.

Jednakże punktem centralnym analiz Valoriego jest pytanie o stosunek fenomenologii do ontologii. $\mathrm{W}$ podsumowaniu części historyczno-metodycznej swej pracy, włoski filozof stwierdza, że „metoda fenomenologiczna [...], podczas gdy rozwija całe swe bogactwo $\mathrm{w}$ analizie relacji intencjonalnej, okazuje się niemocna i głucha, kiedy przychodzi stawić czoła specyficznym problemom ontologii”36. W zakończeniu zaś całego dzieła zastanawia się wprost, czy metoda Husserla wyklucza, ignoruje czy zakłada ontologię. Valori uściśla, że mówiąc o fenomenologii, ma na myśli metodę filozofowania według Husserla, a mówiąc o ontologii, ma na myśli klasyczną ontologię realistyczną w jej podstawowych logiczno-metafizycznych założeniach ${ }^{37}$.

Włoski filozof powiada, że w aspekcie metodologicznym fenomenologia ignoruje ontologię. Pod względem budowania doktryny, czyli próby zrozumienia rzeczywistości, fenomenologia zdaje się ją wykluczać. Pewne elementy metody fenomenologicznej mogłyby jednak być,

34 Zob. P. Valori, Il metodo fenomenologico..., dz. cyt., s. 184.

35 P. Valori, Il metodo fenomenologico..., dz. cyt., s. 184.

36 P. Valori, Il metodo fenomenologico..., dz. cyt., s. 179. Na ten aspekt jego poglądów wskazuje również Frederick J. Crosson w recenzji dzieła Valoriego: F. J. Crosson, P. Valori, Il metodo fenomenologico e la fondazione della filosofia, „Philosophical Studies” 1960 n. 10, s. 299-300.

37 Zob. P. Valori, Il metodo fenomenologico..., dz. cyt., s. 198. 
utrzymuje Valori, wstępem do „czystego spojrzenia” na byt, spojrzenia niezniekształconego przez założenia dogmatyczne czy mitologiczne $e^{38}$. Jest to możliwe, gdyż po dokładniejszej analizie okazuje się, że fenomenologia „nie tylko nie wyklucza ontologii, ale zmierza do niej w sposób oczywisty, nawet jeśli nie chciała czy nie mogła do niej dotrzeć" ${ }^{39}$. Włoski myśliciel uważa, że jest to możliwe, jeśli przyjmie się fenomenologię w jej postaci umiarkowanej, pomijając tezy krańcowe, które nie wydają się przynależeć do jej istoty. Wymienia przykładowo: epochè w sensie gnozeologicznym czy zbyt daleko idące rozróżnienie świadomość-byt ${ }^{40}$.

Valori zastanawia się również, jakimi cechami powinna charakteryzować się ontologia wynikająca z założeń fenomenologii i na niej oparta. Podaje zatem, że powinna być antynaturalistyczna, mniej dedukcyjno-racjonalistyczna, nie może być egzystencjalistyczno-finitystyczna. Powinna zachować otwartość Cogito na rzeczywistość rzeczy samych, co pozwoli na oczyszczenie spojrzenia właściwego czystemu doświadczeniu, następnie zintegrować to spojrzenie w tematyzacji dynamizmu świadomości oraz pogłębić analizę intersubiektywności ${ }^{41}$.

W kolejnych latach publikuje artykuły dotyczące problemów etycznych, relacji filozofii do nauk humanistycznych oraz kontynuuje dociekania nad fenomenologią. Nadal prowadzi badania nad zagadnieniem przejścia od fenomenologii do ontologii. Ważną pracą tego okresu jest Per un discorso ontologico concreto ${ }^{42}$, w której pokazuje „jak można by dziś stworzyć dyskurs ontologiczny konkretny, przeżyty, egzystencjalny, źródłowy - zatem nie naturalistyczny, logicystyczny, abstrakcyjny czy formalistyczny” ${ }^{33}$. Chodzi zatem o zarys "nowej ontologii, naukowej, ale nie scjentystycznej, obiektywnej, ale nie obiektywistycznej, osobowej,

38 Zob. P. Valori, Il metodo fenomenologico..., dz. cyt., s. 199.

39 P. Valori, Il metodo fenomenologico..., dz. cyt., s. 201.

40 Zob. P. Valori, Il metodo fenomenologico..., dz. cyt., s. 200.

41 Zob. P. Valori, Il metodo fenomenologico..., dz. cyt., s. 204-205.

42 P. Valori, Per un discorso ontologico concreto, Roma 1967 (wydanie samodzielne lub jako fragment w: „L'Essere”. Problema - Teoria - Storia, a cura di M. Mancini, Roma 1967).

43 P. Valori, Per un discorso..., dz. cyt., s. 28. 
ale nie subiektywnej" ${ }^{44}$. Taki typ ontologii, twierdzi Valori, mógłby dawać podstawę i wyjaśnienie dla życia moralnego i religijnego. Tę myśl rozwija on w dalszych etapach swojej twórczości.

\section{Autorska koncepcja etyki fenomenologicznej}

Zainteresowanie metodą fenomenologiczną otwiera przed Valorim kolejny obszar badawczy, mianowicie aplikację metody fenomenologicznej do badań nad moralnością. Owocem badań jest książka wydana w 1971 roku: L'esperienza morale. Saggio di una fondazione fenomenologica dell'etica ${ }^{45}$. Jest to „analiza fenomenologiczna, według metody Husserla i Schelera, doświadczenia moralnego. Innymi słowy stawia pytanie, czy dziś można jeszcze mówić o fakcie moralnym i w jakim sensie. To powszechnie używane pojęcie wywoływało i wywołuje ciągłe zamieszanie, polemiki i nieporozumienia, często wzbudza kpiny, prowokuje [...] rozbieżne reakcje uczuciowe, pozytywne i negatywne. Nie umniejsza to jednak i nie może umniejszyć faktu, że to, co mniej więcej oznacza ten termin, konstytuuje jeden $\mathrm{z}$ istotnych elementów życia ludzkiego i dlatego jest godny starannego rozważenia i pogłębienia"46.

Zdaniem Valoriego moralność może być przedmiotem analizy fenomenologicznej, czyli opisu znaczenia tego fenomenu i jego jawienia się w świadomości. Akt moralny rozumie on jako „wolny i świadomy akt człowieka zmierzający do wartości etycznej lub jej braku, czyli do realizowania lub nierealizowania godności osoby własnej lub drugiego" ${ }^{\text {47 }}$.

Przed przejściem do właściwej analizy doświadczenia moralnego filozof ten bada dane problemu moralnego, przede wszystkim cechy charakterystyczne kondycji osoby ludzkiej, aby ukazać trudności w namyśle

44 P. Valori, Per un discorso..., dz. cyt., s. 28.

45 P. Valori, Lesperienza morale. Saggio di una fondazione fenomenologica delletica, Brescia $1971^{1}$ $\left(1976^{2}, 1985^{3}\right)$. W artykule niniejszym korzystam w wydania trzeciego.

46 P. Valori, L'esperienza morale..., dz. cyt., s. 9.

47 P. Valori, Filosofia morale e scienze umane, w: Ricerca morale e scienze umane, a cura di A. Molinario, Bologna 1979, s. 50. 
nad problematyką moralną ${ }^{48}$. Ukazuje również przykłady niewystarczających wyjaśnień faktu moralnego, takie jak neopozytywizm, podejście socjologiczne, strukturalizm czy stanowisko psychoanalityczne ${ }^{49}$.

Pierwszym krokiem badania moralności jest określenie tła analizy, jej background. Tak nazywa Valori zbadanie okoliczności faktu moralnego przy pomocy nauk humanistycznych, wśród których wymienia: biologię, socjologię, psychologię, psychoanalizę, analizę lingwistyczną, antropologię kulturową i strukturalną, semantykę, etnologię czy historiografię ${ }^{50}$. Uważa, że nauki humanistyczne pomagają zdobyć wiedzę o akcie moralnym i właściwie go ocenić.

Kolejny krok wyznacza właściwe badanie doświadczenia moralnego, rozpoczynające się od analizy fenomenologicznej wewnętrznego sądu wartościującego, który Valori rozumie jako „akt egzystencjalnie przeżyty, wypływający z samych korzeni natury ludzkiej, w którym podmiot - w poszukiwaniu sensu i znaczenia swego życia - uznaje wartość tych działań, które wydają mu się bardziej stanowić i wzbogacać to znaczenie" ${ }^{11}$. Sąd wartościujący ukazuje się jako posiadający „swą własną specyfikę wyrażającą uznanie dla ludzkiego losu [...], relację nie z umiejętnością, siłą fizyczną, zewnętrznym sukcesem, zgodnością z prawem społecznym, politycznym, rodzinnym, religijnym itp., ale relację z godnością osoby ludzkiej w sobie samej, właśnie dlatego, że jest ona osobą ludzką"52.

Valori twierdzi, że analiza fenomenów doświadczenia moralnego, jak wspomnianych wyżej sądów wartościujących, ale również fenomenu żalu czy obowiązku, prowadzi do wniosku, że należy odróżnić doświadczenie moralne od innych doświadczeń ludzkich, zwłaszcza związanych

48 Zob. P. Valori, Lesperienza morale..., dz. cyt., s. $31 \mathrm{nn}$.

49 Por. P. Valori, L'esperienza morale..., dz. cyt., s. 55nn.

50 Ten pierwszy krok jest opisany jako pierwszy etap badania moralności w artykule Significato e metodologia della ricerca morale oggi. Scienze umane, filosofia, teologia, „Gregorianum” 58 (1977) n. 1, s. 55-86. Ten sam schemat pojawia się później w tekście Dalla fenomenologia alla ontologia morale z 1982 roku, o którym zob. przypis 58.

51 P. Valori, Lesperienza morale..., dz. cyt., s. 130.

52 P. Valori, Lesperienza morale..., dz. cyt., s. 137-138. 
z życiem społecznym, religijnym i estetycznym ${ }^{53}$. Takie odróżnienie pozwala na uznanie istnienia specyficznego typu wartości, mianowicie wartości moralnej. Włoski filozof rozumie wartość moralną jako „doskonałość lub jakość nieodłączną od aktu ludzkiego (wewnętrznego lub zewnętrznego), gdy on jawi się jako autentycznie ludzki, zgodny z godnością osoby, i odpowiadający najgłębszemu sensowi jej egzystencji”" ${ }^{\text {". }}$. Jako dobre można zatem określić „to zachowanie, które dowartościowuje człowieka, przy czym człowieka rozumiemy tu nie jako abstrakt (społeczeństwo, ojczyzna, ludzkość, Rozum, Natura itd.), ale jako osobę realną, konkretną, pojedynczą, istniejącą w intersubiektywności osób, a co za tym idzie, charakteryzującą się pewnym charakterem absolutności, jakkolwiek odczuwanym czy rozumianym" ${ }^{\prime 25}$. W tekście Significato e metodologia della ricerca morale oggi rozwija tę myśl i zauważa: „godność osoby ludzkiej, mojej lub drugiego - nieoddzielona, ale zjednoczona we wspólnocie innych osób - konstytuuje zatem kryterium istotowe każdego sądu moralnego. Zachowanie lub działanie, indywidualne lub wspólne, jest o tyle bardziej uczciwe, o ile bardziej realizuje tę godnośćn" ${ }^{\prime \prime}$.

\section{Przejście do ontologii moralnej}

Kolejnym etapem badań nad moralnością jest, według Valoriego, przejście od analizy fenomenologicznej do ontologii. Ta droga wydaje się „żmudniejsza i trudniejsza, ale również solidniejsza i bardziej przekonująca" ${ }^{37}$. W dziele L'esperienza morale przedstawia on perspektywy tego kolejnego etapu i wstępnie charakteryzuje ontologię moralną ufundowaną na bazie fenomenologii. Powtarza w tym kontekście, precyzując niektóre sformułowania, rozwiązania proponowane już w Il metodo fenomenologico 1959 roku, jednakże pełne rozwinięcie tej myśli znajduje się w skrypcie dla studentów z 1982 roku o tytule: Dalla fenomenologia

\footnotetext{
53 Zob. P. Valori, Lesperienza morale..., dz. cyt., s. 154.

${ }_{54}$ P. Valori, L'esperienza morale..., dz. cyt., s. 179.

55 P. Valori, Lesperienza morale..., dz. cyt., s. 180.

56 P. Valori, Significato e metodologia della ricerca morale oggi, dz. cyt., s. 79.

57 P. Valori, L'esperienza morale..., dz. cyt., s. 238.
} 
alla ontologia morale. I grandi sistemi etici: il kantismo, il collettivismo, lesistenzialismo ${ }^{58}$. Potrzebę przejścia do ontologii Valori tłumaczy tym, że fenomenologia może prowadzić do odkrycia wartości moralnej, ale "nie tematyzuje fundamentu ontologicznego takiej wartości" ${ }^{\text {" }}$. Innymi słowy, tłumaczy włoski filozof, na podstawie analizy fenomenologicznej można dojść do wniosku, że zabicie niewinnego jest złe, ponieważ jest działaniem przeciw godności osoby, ale nie da się wyjaśnić, dlaczego osoba tę godność posiada ${ }^{60}$. Chodzi zatem o znalezienie fundamentu dla namysłu nad moralnością. Valori powiada, że „człowiek nie może się zadowolić stwierdzeniem, że norma i obowiązek moralny istnieją w jego sumieniu: chce on także znać przyczyny i ostateczne uzasadnienie, które sankcjonują ich roszczenia, często bardzo twarde i ciężkie" ${ }^{\text {. }}$.

Valori powiada również, że „niektóre wielkie prawdy metafizyczne jak [...] godność osoby, wolność woli, otwartość na Absolut itp. - konstytuują faktycznie jedyny możliwy horyzont opisu moralności. Ale in ordine inventionis - powiedzielibyśmy, że są one najpierw przeżywane i odkrywane [...], a później wyrażane pojęciowo"62. W ten sposób analiza fenomenologiczna prowadzi do fundamentu ontologicznego.

Warto dodać jeszcze, że przejście z drugiego do trzeciego etapu badania moralności wymaga, według włoskiego filozofa, dokonania analizy różnych systemów interpretacji doświadczenia moralnego. Bada on przede wszystkim system kantowski, kolektywistyczny, egzystencjalny oraz personalistyczny. Chodzi o analizę „rozwiązań niedoskonałych

58 P. Valori, Dalla fenomenologia alla ontologia morale. I grandi sistemi etici: il kantismo, il collettivismo, l'esistenzialismo, Roma $1982^{1}\left(1988^{2}, 1993^{3}\right)$. W artykule niniejszym korzystam z wydania drugiego. Pierwszy rozdział tej pracy został opublikowany w 1980 roku w czasopiśmie „Aquinas”: P. Valori, Dalla fenomenologia alla ontologia della vita morale, „Aquinas” 23 (1980) q. 3, s. 481498. Jeszcze wcześniej pewne rozważania pojawiają się w artykule cytowanym już wyżej: P. Valori, Significato e metodologia della ricerca morale oggi, dz. cyt., s. 55-86.

59 P. Valori, Dalla fenomenologia..., dz. cyt., s. 19.

60 Zob. P. Valori, Dalla fenomenologia..., dz. cyt., s. 19.

${ }^{61}$ P. Valori, Dalla fenomenologia..., dz. cyt., s. 7.

62 P. Valori, L'esperienza..., dz. cyt., s. 237. 
bądź błędnych [...], aby dojść do pozytywnego wytłumaczenia faktu moralnego"63.

Valori konstatuje, że po dojściu w analizie doświadczenia moralnego do fundamentów ontologicznych osiąga się granicę namysłu filozoficznego. Można jednak kontynuować badanie, otwierając się na wiarę, i w ten sposób dojść do czwartego etapu analizy, czyli teologii moralnej ${ }^{64}$. W tekście Può esistere una morale "laica"? Valori powiada, że analiza fenomenologiczna doświadczenia moralnego prowadzi do ukazania, że „wartość moralna znajduje swoje kryterium gnozeologiczne i bliższy fundament ontologiczny w godności ludzkiej”65. Fundament ostateczny znajduje ona jednak tylko przy odwołaniu się do Absolutu.

Zagadnienie możliwości zastosowania metody fenomenologicznej do badania moralności pozostaje w kręgu zainteresowania Valoriego. Kolejne lata przynoszą szereg tekstów, obok już wymienionych, dotyczących etyki personalistycznej, metodologii badań nad moralnością czy ogólnie dotyczących fenomenologii i przejścia do ontologii moralnej.

Jego ostatni większy tekst to wydana w 1987 roku książka Il libero arbitrio. Dio, l'uomo, la libertá ${ }^{66}$. Dokonuje w nim analizy fenomenu wolnej woli, rozpoczynając od historyczno-krytycznego zarysu zagadnienia w myśli greckiej, przez koncepcje chrześcijańskie starożytności i średniowiecza po filozofię współczesną charakteryzującą się napięciem pomiędzy determinizmem (racjonalizm, pozytywizm, mechanizm, psychologizm, materializm, socjologizm) i indeterminizmem (egzystencjalizm, woluntaryzm, witalizm, fideizm) ${ }^{67}$. Jest to niezwykle ciekawy przegląd stanowisk filozoficznych dotyczących wolnej woli. Według Valoriego wymiar historiograficzny jest ważny, ponieważ ukazuje zawiłość tematu, pomyłki i niebezpieczeństwo popadnięcia we wspomniany determinizm lub indeterminizm. Włoski filozof porównuje

63 P. Duchliński, A. Kobyliński, R. Moń, E. Podrez, Inspiracje chrześcijańskie..., dz. cyt., s. 179.

64 Zob. P. Valori, Dalla fenomenologia..., dz. cyt., s. 20.

65 P. Valori, Può esistere una morale „laica”?, „Civiltà Cattolica” 3 (1984) n. 135, s. 28.

66 P. Valori, Il libero arbitrio. Dio, l'uomo e la libertà, Milano 1987.

67 Zob. P. Valori, Il libero arbitrio, dz. cyt., s. 12. 
badanie do nawigacji i lawirowania pomiędzy mitologiczną Scyllą i Charybdą ${ }^{68}$.

W analizie systematycznej fenomenu wolnej woli Valori wychodzi od stwierdzenia, że „z poznawczego punktu widzenia doświadczenie moralne nie poprzedza doświadczenia wolności, ale zachodzą one równocześnie, zawierają się w sobie. Nie ma moralności bez wolności, ale nie istnieje również idea wolności bez ujawniającej się natychmiast idei moralności” ${ }^{69}$. Badanie tego fenomenu doprowadza go natomiast do odróżnienia wolnej woli od iluzji wyboru, jak chciał Spinoza. Valori przeciwstawia się twierdzeniom nowożytnego racjonalizmu, jakoby czynniki racjonalne miały deterministyczny wpływ na wolę człowieka. Wolna wola nie jest jednak irracjonalna, nie jest absolutna, doskonała. Nie można jej także pojmować jako nieznośnego ciężaru ${ }^{70}$.

Czym zatem jest wolna wola w rozumieniu Valoriego? Rozumie on ją jako „autodeterminację lub samopanowanie, częściowe i skończone, osoby jako intelektu i woli, osoby rozumianej w swej integralności i całościowości, która wyłania się ze swych uwarunkowań jako aktywny projekt życia i działania"71.

Analiza fenomenu wolnej woli również doprowadza Valoriego do twierdzenia, że potrzebna jest nowa ontologia, w tym przypadku nowa „ontologia Wolności”. Jej ważnymi elementami mogłyby być godność osoby ludzkiej i jej otwarcie na Transcendencję ${ }^{72}$.

Ostatnie lata życia Valoriego przynoszą, obok recenzji i artykułu na temat utylitaryzmu, dwa teksty, na które warto zwrócić uwagę. Pierwszym z nich jest hasło Wartość moralna w Nowym słowniku teologii moralnej wydanym w 1990 roku $^{73}$. Valori prezentuje w tekście koncepcję specy-

68 Zob. P. Valori, Il libero arbitrio, dz. cyt., s. 76.

69 P. Valori, Il libero arbitrio, dz. cyt., s. 99.

70 Zob. P. Valori, Il libero arbitrio, dz. cyt., s. 156-158.

${ }^{71}$ P. Valori, Il libero arbitrio, dz. cyt., s. 158. Por. P. Duchliński, A. Kobyliński, R. Moń, E. Podrez, Inspiracje chrześcijańskie w etyce, dz. cyt., s. 182.

72 Zob. P. Valori, Il libero arbitrio, dz. cyt., s. 159.

73 P. Valori, Valore morale, w: Nuovo dizionario di teologia morale, a cura di F. Compagnoni, G. Piana, S. Privitera, Milano $1994^{3}\left(1990^{1,2}\right)$, s. 1416-1427. 
ficznej i osobliwej wartości moralnej, odróżniając ją od wartości empiryczno-emotywnych, utylitarnych, estetycznych czy religijnych ${ }^{74}$. Także $\mathrm{w}$ tym tekście wybrzmiewa potrzeba znalezienia ostatecznego fundamentu moralności. Valori, powołując się na Schelera, twierdzi, że „wartość moralna polega w swej istocie na dostrzeżeniu godności osoby ludzkiej na poziomie teoretycznym oraz na poszanowaniu tej godności na poziomie praktycznym"75. Pozostaje jednak pytanie o źródło tej godności. Odpowiedź musi odsyłać do „antropologii ontologicznej, która będzie afirmować wolność, duchowość, nieśmiertelność osoby i jej uczestnictwo w wartości i Bycie Absolutnym"76. Owe prawdy metafizyczne, jak je nazywa Valori, nie muszą być jednak zakładane a priori. Nie muszą być przyjmowane $\mathrm{w}$ sensie fideistycznym ani postulowane $\mathrm{w}$ sensie kantowskim. Są one „koniecznie przeżyte jako horyzont egzystencjalny, w którym doświadczenie moralne się naturalnie otwiera i ukierunkowuje" ${ }^{37}$.

Drugim ze wspomnianych tekstów jest wywiad Faustina Parisiego przeprowadzony z Valorim 28 lutego $2002 \mathrm{w} \mathrm{Rzymie}^{78}$. Jest to zatem ostatni zapis poglądów Valoriego wyrażonych w czasie rozmowy niecałe dwa lata przed jego śmiercią 23 grudnia 2003 roku. W rozmowie powtarza on najważniejsze tezy swojej koncepcji etyki fenomenologicznej: niewystarczalność dotychczasowych rozwiązań, istnienie wartości moralnej i potrzebę przejścia do ontologii moralnej. Zauważa również, że jego działalność filozoficzna zatrzymała się na progu przejścia do teologii moralnej, ale nie poszła dalej ${ }^{79}$. W wywiadzie stwierdza ponadto wprost, że jego podejście do zagadnień etyki ma charakter schelerowski, co oczywiście było zauważalne, ale otwiera również perspektywę zbadania, w jakim stopniu jego koncepcja etyki opiera się na rozwiązaniach Schelera i w jakim je udoskonala.

74 P. Valori, Valore morale, dz. cyt., s. 1418.

75 P. Valori, Valore morale, dz. cyt., s. 1426.

76 P. Valori, Valore morale, dz. cyt., s. 1426.

77 P. Valori, Valore morale, dz. cyt., s. 1427.

78 F. Parisi, Intervista al prof. Paolo Valori S.J., w: F. Parisi, Il valore della coscienza e dellesperienza morale, Bari 2003, s. 7-14.

79 Zob. F. Parisi, Intervista..., dz. cyt., s. 14. 


\section{Zakończenie}

Valori, zajmując się myślą Husserla, jego metodą filozofowania, zajął ważne miejsce w historii filozofii współczesnej. Był jednym z najważniejszych przedstawicieli fenomenologii we Włoszech. Pozostawił po sobie kilka książek, kilkadziesiąt artykułów i fragmentów prac zbiorowych, w tym: wstępów do książek, haseł encyklopedycznych i słownikowych, głosów w dyskusjach, a także kilkadziesiąt recenzji. Ważne są szczególnie dzieła dotyczące metody fenomenologicznej, a zwłaszcza jej zastosowania do badania doświadczenia moralnego. Korzystając z pomocy nauk humanistycznych, wykazując ich ważną, aczkolwiek niewystarczającą rolę, przedstawia w licznych tekstach koncepcję etyki fenomenologicznej. Analiza fenomenologiczna prowadzi do odkrycia specyfiki faktu moralnego i wartości moralnej. Valori postuluje również potrzebę znalezienia fundamentu wartości moralnych dzięki ontologii moralnej.

\section{Bibliografia}

Banfi A., La fenomenologia pura di E. Husserl e l'autonomia ideale della sfera teorica, „Rivista di filosofia" 14 (1923) q. 3, s. 208-224.

Banfi A., La tendenza logistica della filosofia tedesca contemporanea e le „Ricerche logiche” di Edmund Husserl, „Rivista di filosofia”14 (1923) q. 2, s. 115-133.

Crosson F. J., P. Valori, Il metodo fenomenologico e la fondazione della filosofia, „Philosophical Studies" 1960 n. 10, s. 299-300.

Duchliński D., Kobyliński A., Moń R., Podrez E., Inspiracje chrześcijańskie w etyce, Kraków 2016.

Egaña F., In memoriam: P. Paolo Valori, „La Gregoriana. Trimestrale della Pontificia Università Gregoriana” 2004 n. 20, s. 29.

Husserl E., Dal manoscritto inedito K III 26, P. Valori (tłum.), „Archivio di filosofia” 22 (1954) n. 1, s. 173-175.

Husserl E., Dal manoscritto inedito K III 28, P. Valori (tłum.), „Archivio di filosofia” 22 (1954) n. 1, s. 168-172.

Husserl E., Die Idee der Phänomenologie. Fünf Vorlesungen, Haag 1950. 
Jaegerschmid A., Rozmowy z Edmundem Husserlem (1931-1938), „Znak” 1972 nr 212, s. 153-185.

Kijowski R., Fenomenologia Edyty Stein, w: Edyta Stein - filozof i świadek epoki. Materiały z Międzynarodowego Sympozjum w Opolu - Kamieniu Ślaskim w dniach 9-10.04.1997, red. J. Piecuch, Opole 1997, s. 19-30.

Kobyliński A., Włoska droga do fenomenologii. Paolo Valori - interpretacja doświadczenia moralnego, w: Dziedzictwo etyki współczesnej. Aksjologia i etyka Romana Ingardena i jego uczniów. Studia i rozprawy, red. P. Duchliński, Kraków 2015, s. 313-330.

Mocchi M., Le prime interpretazioni della filosofia di Husserla in Italia. Il dibattito sulla fenomenologia: 1923-1940, Firenze 1990.

Parisi F., Intervista al prof. Paolo Valori S.J., w: F. Parisi, Il valore della coscienza e dell'esperienza morale, Bari 2003, s. 7-14.

Sini C., La fenomenologia in Italia, „Revue Internationale de philosophie” 1965 n. 71/72, s. $125-139$.

Valori P., Dalla fenomenologia alla ontologia della vita morale, „Aquinas” 23 (1980) q. 23, s. $481-498$.

Valori P., Dalla fenomenologia alla ontologia morale. I grandi sistemi etici: il kantismo, il collettivismo, l'esistenzialismo, Roma $1988^{2}$.

Valori P., E. Husserl, Die Idee der Phänomenologie. Fünf Vorlesungen, „Gregorianum” 33 (1952) n. 1, s. 196-197.

Valori P., Lesperienza morale. Saggio di una fondazione fenomenologica dell'etica, Brescia $1985^{3}$.

Valori A., Il fascista che non amava il regime, a cura di V. Tonelli Valori, Roma 2003.

Valori P., Filosofia morale e scienze umane, w: Ricerca morale e scienze umane, a cura di A. Molinario, Bologna 1979.

Valori P., Inediti husserliani sulla teleologia della storia, „Archivio di filosofia” 22 (1954) n. 1, s. $165-167$.

Valori P., Il libero arbitrio. Dio, l'uomo e la libertà, Milano 1987.

Valori P., M. Blondel e il problema d'una filosofia cristiana, Roma 1950.

Valori P., Il metodo fenomenologico e la fondazione della filosofia, Città di Castello 1959.

Valori P., Per un discorso ontologico concreto, Roma 1967.

Valori P., Il problema del soprannaturale e gli ultimi scritti di M. Blondel, „Civiltà Cattolica” 1 (1949) n. 100, s. 161-170.

Valori P., Può esistere una morale „laica”?, „Civiltà Cattolica” 3 (1984) n. 135, s. 19-29. 
Valori P., Significato e metodologia della ricerca morale oggi. Scienze umane, filosofia, teologia, „Gregorianum” 58 (1977) n. 1, s. 55-86.

Valori P., Il soprannaturale e gli ultimi scritti di M. Blondel, „Civiltà Cattolica” 1 (1949) n. 100 , s. 392-399.

Valori P., Storia della fenomenologia husserliana, w: La fenomenologia, a cura di C. M. Antonelli, Brescia 1956, s. 68-84.

Valori P., Valore morale, w: Nuovo dizionario di teologia morale, a cura di F. Compagnoni, G. Piana, S. Privitera, Milano 1994³ s. 1416-1427.

\section{Abstrakt}

\section{Filozoficzna droga Paola Valoriego}

Celem artykułu jest przedstawienie filozoficznej twórczości Paola Valoriego (19192003). Był on jednym $z$ najważniejszych przedstawicieli fenomenologii we Włoszech. Analiza jego głównych tekstów pozwala zaprezentować drogę do zainteresowania fenomenologią, zwłaszcza koncepcję fenomenologicznej analizy doświadczenia moralnego. Valori ukazuje specyfikę doświadczenia moralnego, a także postuluje potrzebę ontologii moralnej. Artykuł ukazuje źródła tego przekonania oraz proponowane cechy takiej ontologii.

\section{Słowa kluczowe}

Paolo Valori, fenomenologia, ontologia, etyka, doświadczenie moralne

\section{Abstact \\ Phenomenological interpretation of moral experience. Philosophical path of Paolo Valori}

The aim of the article is to present philosophical works of Paolo Valori (1919-2003) one of the most significant phenomenologists in Italy. The study of his major works illustrates his path to phenomenology and his phenomenological analysis of moral experience in particular. Valori demonstrates the specificity of moral experience and advocates a need for moral ontology. The article points at the sources of Valori's conviction and outlines features of such ontology. 


\section{Keywords}

Paolo Valori, fenomenology, ontology, ethics, moral experience 